\title{
ZAKAT AS TAX REDUCTION: STUDY OF MUSLIM COMMUNITY PERCEPTION IN INDONESIA AND MALAYSIA
}

\author{
Aula Ahmad Hafidh Saiful Fikria \\ Fuadah Johari ${ }^{\mathrm{b}}$ \\ Maimun Sholeh ${ }^{c}$ \\ Eko Suprayitno ${ }^{d}$ \\ Ngadiyono ${ }^{e}$ \\ a,c,e Economic Education Department, Faculty of Economics, Yogyakarta State University \\ ${ }^{b}$ Economics Department, Faculty of Economics and Muamalat, Universiti Sains Islam Malaysia \\ dIslamic Banking Department, Faculty of Economics, State Islamic University Maulana Malik \\ Ibrahim \\ Email: aula hsf@uny.ac.id ${ }^{a}$; fuadah@usim.edu.my ${ }^{\text {; }}$; maimunsholeh@uny.ac.id ${ }^{c}$; \\ ekonashwan@gmail.com ${ }^{\text {; }}$, ngadiyono@uny.ac.id ${ }^{\mathrm{e}}$
}

ARTICLE HISTORY

Received:

08 August 2021

Revised

07 November 2021

Accepted:

22 November 2021

Online available:

30 November 2021

Keywords:

Zakat,

Tax Reduction, Moslem Perception, Indonesia,

Malaysia.

*Correspondence:

Name:

Aula Ahmad Hafidh

E-mail:

aula hsf@uny.ac.id

\section{ABSTRACT}

This study aims to examine the model adopted based on Muslim consumer perceptions of taxes through the zakat system. This research uses three stages of comprehensive technical analysis through demographic depiction of respondents based on distribution frequently, then tests the adopted factors using Exploratory Factor Analysis (EFA) to select and determine the number of factors and related items. In the final stage, data analysis is carried out in the form of the modeling technique using Structure Equations Model (SEM) to test the quality of the models and hypotheses produced. 152 respondents were collected who were sampled in this study, the majority of respondents are 77 Malaysian citizens and 75 Indonesian residents. At the testing stage of the model through the Structural Equation Model (SEM), based on the results of the formation factors in the test, it can be said that only the knowledge about tax, religious, and service variables have an impact on perception toward through zakat system positively and significantly, but through testing the serviceability of a model results in a determinant coefficient of 0.668 , which it was relatively strong to explaining independent variable.

\section{INTRODUCTION}

Islamic philosophy prioritizes its main goals to the interests of society rather than personal or group interests. Islamic philosophy is different from western philosophy which is based on self-interest and is individualistic which glorifies individual freedom 
and prioritizes individual ownership, or communists who prioritize government ownership and give power to the government to oppress the people (Ghazali, 2007). Therefore, Islam establishes clear and firm rules to be implemented throughout the ages for the government to manage the country fairly and wisely to achieve the welfare of the people. One of the Islamic regulations that allow the government to get a source of funds to run the country is tax and zakat.

Meanwhile, zakat is different from tax. Zakat is a religious responsibility. As for people who believe in the obligation to give zakat but are reluctant to pay or fulfill these obligations because of hunks and misers, then their zakat may be forcibly taken by the government. The government takes it forcibly because the zakat property is the right of the poor, which is an obligation that must be fulfilled by the zakat obligation.

The management of zakat in Indonesia is regulated in Law Number 23 the Year 2011 concerning Zakat Management, and Government Regulation (PP) Number 14 Year 2014 concerning Implementation of the Law on Zakat Management. The two regulations are structured as the basis for receiving and managing zakat so that they are well organized and able to provide benefits for the guidance of the people.

As a country with the largest Muslim population according to BPS (2010),

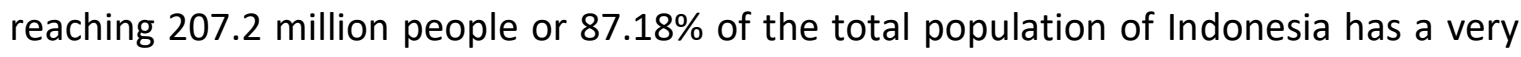
large potential for zakat. Indonesia's large zakat potential is influenced by the demographic transition which is increasingly dominated by the young productive generation and the development of the middle class in the digital economy era. Currently, the number of middle-class people is around 52 million. This number will increase, which states that Indonesia has the potential to become a developed country (number 7) by 2030, and the number of the middle class is estimated to reach 135 million people. The increase in the number of middle-class people will increase the potential value of zakat in Indonesia. Mapping the potential for zakat is one part of the pillars of the Indonesian zakat architecture, namely pillar III concerning the national zakat institution which includes a system of collection, distribution, and utilization. Mapping the potential for zakat with a measurement model that considers the specific variables of a region is needed to see how many zakat potential figures can be collected in a particular area. This is because each region has different potentials and resources. By detailing and mapping zakat potential by area, it is hoped that it can help zakat institutions in collecting zakat funds effectively and efficiently.

Indonesia is a country with the largest Muslim population in the world and has a huge potential for zakat. Firdaus et al. (2012) revealed that the potential for zakat funds in Indonesia reaches IDR 217 trillion per year or the equivalent of 3.4\% of Indonesia's Gross Domestic Product (GDP) in 2010. If every muzakki (obliged to zakat) realizes and 
makes zakat payments, then the Islamic redistribution fund will be able to assist the government in alleviating poverty and the welfare of society. The large potential of zakat has not been optimally realized. This refers to the data released by BAZNAS, wherein 2017 the amount of zakat, infaq, and alms (ZIS) collected was IDR 6.2 trillion, an increase of $24 \%$ compared to 2016, which was valued at IDR 5 trillion (Puskas BAZNAS, 2019).

Meanwhile, according to the head of the Malaysian Zakat Levies Center Amran Hazali, the collection of zakat in Malaysia in 2016 reached nearly MYR 3 billion (around IDR 11.5). Of this amount, most of the zakat collection comes from Kuala Lumpur and Selangor. In Kuala Lumpur alone, it was almost 600 million ringgit, while in Selangor it was 680 million ringgit. Selangor and Kuala Lumpur account for nearly 50 percent of zakat collection in Malaysia. (World Zakat Forum, 2017). He added that the collection of zakat in Malaysia which reached 3 billion ringgit was only 65-70 percent of the amount that should be collected. So if MYR 3 billion is only 70 percent because there is a factor of muzakki who do not give zakat to registered zakat bodies but pay directly to mustahik.

With the existence of the zakat institution, it is not only for a Muslim to directly hand over the affairs of the distribution of his zakat by the zakat institution. A person who will entrust his/her zakat distribution often carries out several processes of seeking information related to the amil zakat institution in question and what its advantages are. The ease of implementation also affects someone to make the amil institution distribute their zakat. These things are because it is only natural to seek information before doing something, especially with matters related to one's assets and liabilities.

Based on data from the Zakat Organization Forum, there are currently one National Zakat Organization (BAZNAS), 33 Provincial Amil Zakat Bodies (BAZDA), 429 BAZ at city/regency level, and 4771 at the sub-district level. In addition, there are einghteen National Amil Zakat Institutions (LAZ) and 52 LAZ at the provincial, district/city level (FOZ, 2009). However, the number of zakat institutions is not directly proportional to the realization of ZIS receipts. The results of the Public Interest Research and Advocacy Center survey stated that the potential for ZIS and its realization was still far from expectations. The amount of potential each year is IDR20 trillion, but only about IDR trillion or 6\% (PIRAC, 2002).

The low realization of ZIS revenue is due to low compliance, awareness, and public trust in paying ZIS through zakat institutions (Nasution, 2009; Wahid et al., 2005). Individual motivation to pay ZIS by the amil zakat LAZ institution is influenced by the level of religiosity the research results by Farida (2008) stated that the religious index does not have a significant effect on the amount of zakat paid by muzakki. The difference in the results of this research needs further study whether the religiosity factor influences or not on the motivation to pay ZIS. 
Apart from religiosity, one's motivation to take action is due to psychological factors and social factors. The psychological factors in question are perception, knowledge, beliefs, and attitudes. Meanwhile, social factors are a family, community, and institutional/organizational affiliation (Kotler \& Armstrong, 1997). Psychological factors consisting of perceptions, knowledge, attitudes, and personality affect the preference of Muslim employees in paying professional zakat through zakat institutions (Fatah, 2008). The factors that influence the motivation to pay zakat are demographic, social, religious, economic, and available infrastructure factors (Bakar \& Rashid, 2010).

Some of the results of these studies are very clear that psychological factors consisting of perceptions, knowledge, beliefs, and attitudes as well as social factors consisting of family, community, and institutional/organizational affiliations can influence the motivation to pay ZIS at zakat institutions. This research wants to improve those variables with applied in two Moslem country and to introduce new variable with performance of zakat institution. Apart from the above factors, government regulations are thought to affect the motivation to pay ZIS to zakat institutions. Hamidiyah (2008) also stated that government regulations have an effect on collection at zakat institutions. The attributes of zakat institutions also affect people's motivation to pay ZIS to amil zakat institutions. The transformation of ZIS management from traditional to professional management must be supported by the principles of modern management and good governance such as cultivating the principles of transparency, accountability, and professionalism from the Amil Zakat Infaq and Shadaqah Institute (LAZIS) which exist in addition to honesty, commitment, and consistency of the airlines and authorized parties.

Based on the background of the problems above, the formulation of the problems raised in this study is what factors influence muzakki in deciding to pay zakat case studies to Muslim communities in Indonesia and Malaysia.

\section{LITERATURE REVIEW}

\section{Zakat and Tax}

Zakat is "part of human wealth that is reserved for the poor" (Sabiq, 2019). It is also defined as: "a compulsory levy imposed on Muslims for taking extra money or wealth from relatively wealthy members of the Muslim community and giving it to the poor and needy" (Zaim, 1989). On the other hand, tax is defined as "the process of raising money for the benefit of the government through contributions from individuals" (Singh, 2001). Hanson (2021) said that taxes were imposed solely to increase income to cover operational and state development expenditures. In Abbasi, taxes views as a complement (Bakr \& Rahman, 2007). 
Taxes are levied on income or consumption whereas zakat is set to a broader range covering both productive wealth and idle property (Bakar \& Rahman, 2007). Zakat is applied to all items that represent a person's income and is calculated after deducting personal expenses if they reach the nisab (wealth equivalent to 85 grams of gold). This is widely mentioned by many Muslim countries including Malaysia.

Taxation is a mandatory payment to the government based on tax base ownership. The purpose of taxation is to raise funds for administrative and defense costs, and several other public services in the country and also for the expenses of the ruler (Hanson, 2021). There are two types of taxation. One based on the proportional principle means that the tax is proportional to income and the other is based on the progressive principle which means the amount that must be paid because the tax increases more than proportional to the income of the taxpayer. The principle of proportion is strongly supported by the Scottish economist Adam Smith because he considers it the most sensible method of collecting the taxable income of the nation's people (Hanson, 2021).

Zakat and tax are two things that have in common, that is, both are part of the income taken from the taxpayer and the zakat payer to finance certain needs. The Unitary State of the Republic of Indonesia defines taxes as compulsory contributions to the state that are owed by individuals or entities that are compelling based on law without receiving direct compensation and used for state needs for the greatest prosperity of the people, while At-Tuwaijiri (2012) described the linguistic meaning of zakat as developing and increasing, while zakat in term means compulsory rights to certain assets for certain groups at a certain time.

Indonesia's GDP in 2014 reached 10,542.7 trillion rupiah, meaning that the zakat potential should reach 358.45 trillion rupiah, even though the zakat collected in 2014 was only 82.94 trillion rupiah, meaning that the percentage of zakat receipts only reached $23.13 \%$. Third, the majority of zakat collected by BAZNAS and LAZ is income zakat, even though there are many other types of zakat that can be collected that have not been reached by BAZNAS and LAZ. The collection and management of zakat is actually the responsibility of the government at least this was conveyed by (Al-Mawardi, 2006; An-Nabahan, 2000).

\section{Factors Affecting Zakat and Tax Payments}

Previous studies have shown several factors that influence zakat on income payments such as the personality value of zakat payers, zakat enforcement, and efficiency of zakat administrators and knowledge of zakat, except for the study of Bakar et al. (2011). For example, the personal value of an entrepreneur is related to the decision to pay or not pay zakat under the control of the individual (Hanno \& Violette, 
1996). Arif et al. (2011) have designed a framework of attitudes towards zakat on business and subjective norms lead to behavioral intentions and will directly influence actual behavior towards zakat. Attitudes towards zakat are influenced by directors and shareholders. The more directors and shareholders who are Muslim, the higher the tendency to respond to the payment of zakat business.

Strong religious values can increase their willingness to pay taxes for the benefit of the country. However, Khamis et al. (2011) explained in the 8th International Conference on Islamic Economics \& Finance that human behavior (Muslim community) makes decisions (obey or not) to pay zakat (official or unofficial channels) in accordance with laws and regulations are implemented to achieve satisfaction in this life and the hereafter as well as an indication of gratitude to Allah. Consumers' perceptions of zakat and taxes depend on education, religiosity, and law enforcement. Most of the research conducted on zakat in Malaysia concentrates on various fields including theoretical but perhaps somewhat from a marketing and consumer behavior point of view (Bakar \& Rashid, 2010).

A recent study was conducted to examine the impact of culture on perceptions of tax fairness and tax compliance and found no universal cross-cultural relationships based on their investigations in two different regions of Australia and Hong Kong (Gilligan \& Richardson, 2005). Studies reveal that women are more compliant than men (Jackson \& Milliron, 1986; Richardson \& Sawyer, 2001) and less frequently tax evasive or tax evasive (Oxley, 1993). Similar to older taxpayers compared to younger ones (Smith \& Sumitro, 1992).

\section{Previous Study}

Research by Irhamsyah (2019) revealed that the factor of technological knowledge and knowledge of zakat has not proven an influence on the decision to pay zakat digitally, but lifestyle and satisfaction factors have an influence on muzakki choosing to pay zakat digitally. Meanwhile, research by Ma'fiyah et al. (2018) stated that in the aspect of the individual perspective that dominantly influences muzakki to pay zakat to formal zakat institutions in order, is the knowledge of zakat, faith, and religiosity as well as awareness and trust, while in the perspective of the institution in order are management credibility, institutional credibility, service quality and outreach.

Al Jaffri Saad and Haniffa (2014) as well as Azman and Bidin (2015) revealed that attitudes towards behavior and subjective norms and intentions can predict muzakki's behavior in complying with the obligation to pay zakat. In addition, Azman and Bidin (2015) also found that the factor of faith or religiosity is an important factor for muzakki in paying zakat. Previous research which also revealed that religious value (faith) 
influences the compliance behavior of paying zakat is found in research conducted by Idris et al. (2012); Khraim (2010).

As for Firdaus et al. (2012); Muda et al. (2009); Mukhlis and Beik (2013) found that altruism, utilitarianism, satisfaction, and trust are important factors in influencing muzakki in paying zakat. Then in research conducted by Bakar and Rashid (2010); Indahsari (2013), it strengthens the finding that muzakki considers the level of satisfaction and self-confidence as preferences in paying zakat. Then other findings revealed in the research of Firdaus et al. (2012); Indahsari (2013) found that the level of income and employment also influenced muzakki in paying zakat. Besides, there are other factors expressed by Dahlan (2008); Huda et al. (2014); Merlinda et al. (2016), that the important factors in muzakki's compliance in paying zakat are educational factors and Muzakki's knowledge of zakat.

Meanwhile, muzakki's perception of the credibility of the institution is an important factor as muzakki's preference in choosing zakat institutions. This is expressed in research conducted by Firdaus et al. (2012); Mohammed et al. (2008); Mustafa et al. (2013); Zainal et al. (2016). In terms of exposure or management credibility is also an important factor for muzakki in choosing zakat institutions, such as the findings obtained from research by Dahlan (2008); Indahsari (2013); Mustafa et al. (2013); Zainal et al. (2016). In revealing the institutional perspective factor is related to the perception of service quality as expressed in research conducted by Jaelani (2008); Zainal et al. (2016). Then, the perception of institutional socialization is also a reference for muzakki in choosing a zakat institution as concluded by Dahlan (2008); Jaelani (2008). Based on the above description and research results, the hypothesis proposed are:

$\mathrm{H}_{1}$ : Religiosity has a significant effect on the preference for zakat as a tax deduction. $\mathrm{H}_{2}$ : Knowledge has a significant effect on zakat preference as a tax deduction. $\mathrm{H}_{3}$ : Halal and Haram have a significant effect on the preference for zakat as a tax deduction.

$\mathrm{H}_{4}$ : Trust has a significant positive effect on the preference for zakat as a tax deduction.

$\mathrm{H}_{5}$ : Motivation has a significant positive effect on zakat preference as a tax deduction. $\mathrm{H}_{6}$ : Legal awareness has a significant effect on the preference for zakat as a tax deduction.

$\mathrm{H}_{7}$ : Trust has a significant effect on the preference for zakat as a tax deduction.

$\mathrm{H}_{8}$ : Satisfaction has a significant effect on zakat preference as a tax deduction. 


\section{Conceptual Study Framework}

The proposed framework of our current study has been constructed with reference to literature review. This particular model concentrates on Muslim consumers' perceptions of taxes through the zakat system in Malaysia. From this literature review, we explore the independent variables, namely knowledge of zakat, knowledge of taxation, halal-haram aspects, legal awareness, and religiosity to determine the expected relationship with the dependent variable, namely the perception of Muslim consumers towards taxes through the zakat system in Indonesia and Malaysia. Figure 1 below is a picture of the proposed model.

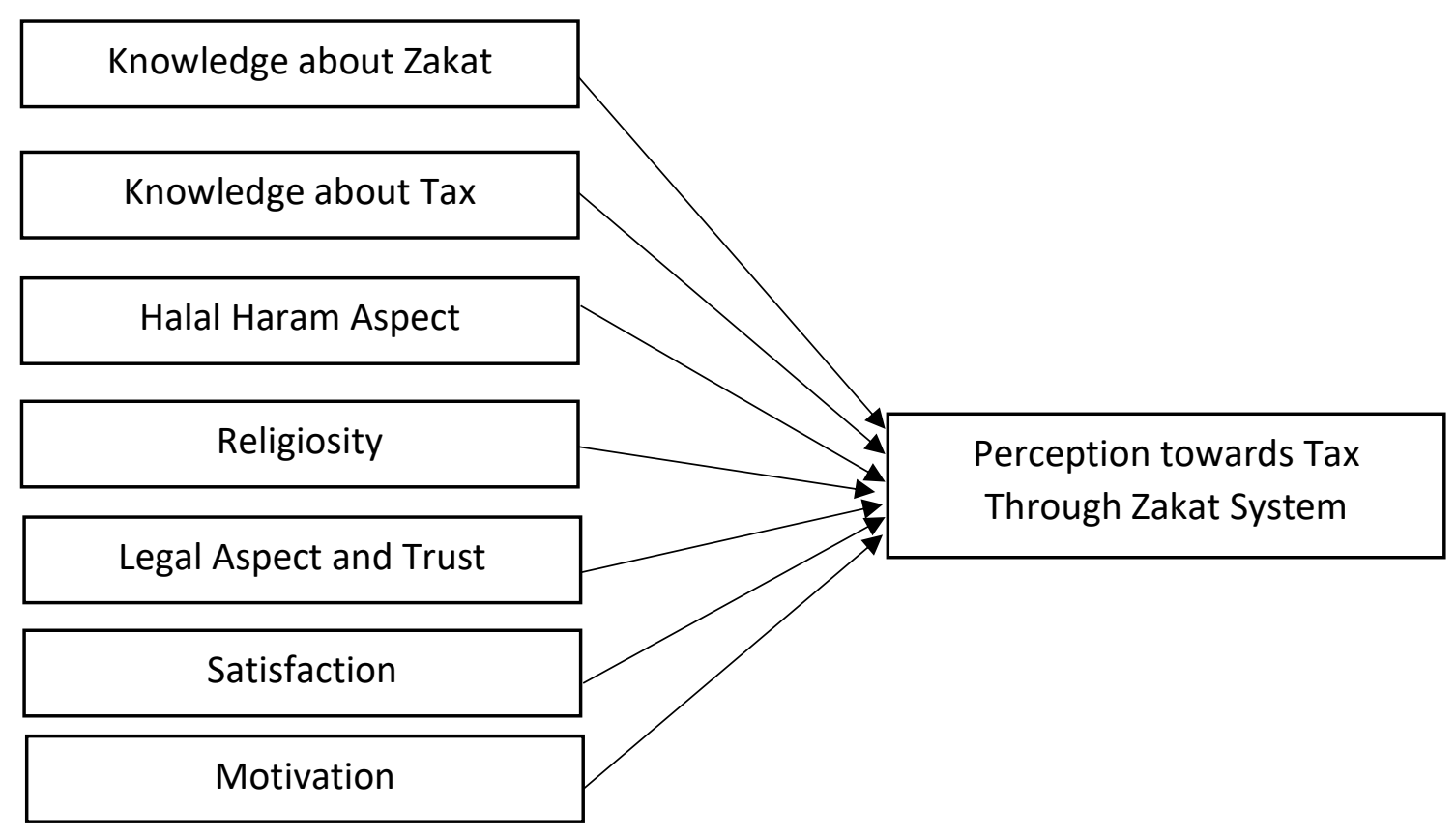

Figure 1. Conceptual Model

\section{RESEARCH METHOD}

Scope of this study is that Muslim communities in Indonesia and Malaysia already have income. The variables used in this study are the variables of religiosity $\left(X_{1}\right)$, knowledge of zakat $\left(X_{2}\right)$, knowledge of taxes $\left(X_{3}\right)$, halal and haram aspects $\left(X_{4}\right)$, legal aspects $\left(X_{5}\right)$, satisfaction $\left(X_{6}\right)$, and motivation $\left(X_{7}\right)$ as the independent variable, and the perception variable using $(\mathrm{Y})$ as the dependent variable.

The population in this study is the Muslim community in Indonesia and Malaysia, while the sample used is Indonesian and Malaysian citizens who are Muslim and already have income. 
In this study, the technique used is probability sampling technique. What is meant by probability sampling is a sampling technique that provides equal opportunities for each element (member) of the population to be selected as a sample member. In this probability sampling using area sampling. Area sampling is an area sampling technique used to determine if a sample the object to be studied or the source of the data, then the sampling is based on a predetermined population area (Sugiyono, 2011). The sample size for the SEM with estimation procedures generally uses MLE.

\section{Operational Variables}

Table 1

Operational Variables

\begin{tabular}{|c|c|c|}
\hline No. & Variables & Indicators \\
\hline \multirow{5}{*}{1} & \multirow{5}{*}{$\begin{array}{l}\text { Knowledge } \\
\text { about Zakat }\end{array}$} & Zakat on income is a religious obligation \\
\hline & & $\begin{array}{l}\text { The minimum amount which is applicable for zakat in } \\
\text { Islam }\end{array}$ \\
\hline & & Zakat is a social obligation towards Muslim Ummah \\
\hline & & Pay $2.5 \%$ of my wealth if zakat is applicable for me \\
\hline & & $\begin{array}{l}\text { With zakat, believe that the economic condition of } \\
\text { the Muslim Ummah will be improved }\end{array}$ \\
\hline \multirow{4}{*}{2} & \multirow{4}{*}{$\begin{array}{l}\text { Knowledge } \\
\text { about Tax }\end{array}$} & $\begin{array}{l}\text { The minimum amount of money for which I have to } \\
\text { pay tax to the government }\end{array}$ \\
\hline & & $\begin{array}{l}\text { Knowledge about the tax rates (\%) according to the } \\
\text { Malaysian Income Tax Act }\end{array}$ \\
\hline & & $\begin{array}{l}\text { Institutions are providing proper information to } \\
\text { motivate the Muslim consumers about this system }\end{array}$ \\
\hline & & $\begin{array}{l}\text { The tax authority is providing proper information to } \\
\text { motivate the Muslim consumers about this system }\end{array}$ \\
\hline \multirow{6}{*}{3} & \multirow{6}{*}{$\begin{array}{l}\text { Halal Haram } \\
\text { Aspect }\end{array}$} & $\begin{array}{l}\text { Strict regarding halal and haram aspects of Islamic } \\
\text { Law or Shariah lawaspects of Islamic law or sharia law }\end{array}$ \\
\hline & & $\begin{array}{l}\text { Ask my friends or scholars about its permissibility in } \\
\text { Islam If I am not clear about anything }\end{array}$ \\
\hline & & $\begin{array}{l}\text { Enjoying tax rebate through payment of zakat is } \\
\text { permissible (halal) in Islam }\end{array}$ \\
\hline & & $\begin{array}{l}\text { Enjoying tax rebate through zakat while I am paying } \\
\text { my tax because I feel it is permitted (halal) }\end{array}$ \\
\hline & & Fulfill the requirements of paying zakat \\
\hline & & Follow Islamic guidelines to lead his life \\
\hline \multirow{6}{*}{4} & \multirow{6}{*}{ Religiosity } & $\begin{array}{l}\text { My religious beliefs influence me to get the } \\
\text { advantage of the tax rebate through charity }\end{array}$ \\
\hline & & $\begin{array}{l}\text { Maintain legal obligations related to tax Because I } \\
\text { feel it protects my social image }\end{array}$ \\
\hline & & $\begin{array}{l}\text { Enjoying tax rebate through zakat is a good system } \\
\text { for Muslims }\end{array}$ \\
\hline & & $\begin{array}{l}\text { Tax rebate through the zakat system is a sign of } \\
\text { religious duty towards the Muslims }\end{array}$ \\
\hline & & $\begin{array}{l}\text { Religious lectures enhance understanding to choose } \\
\text { this system easily without hesitation }\end{array}$ \\
\hline & & The info rmation of religious books and magazines \\
\hline
\end{tabular}




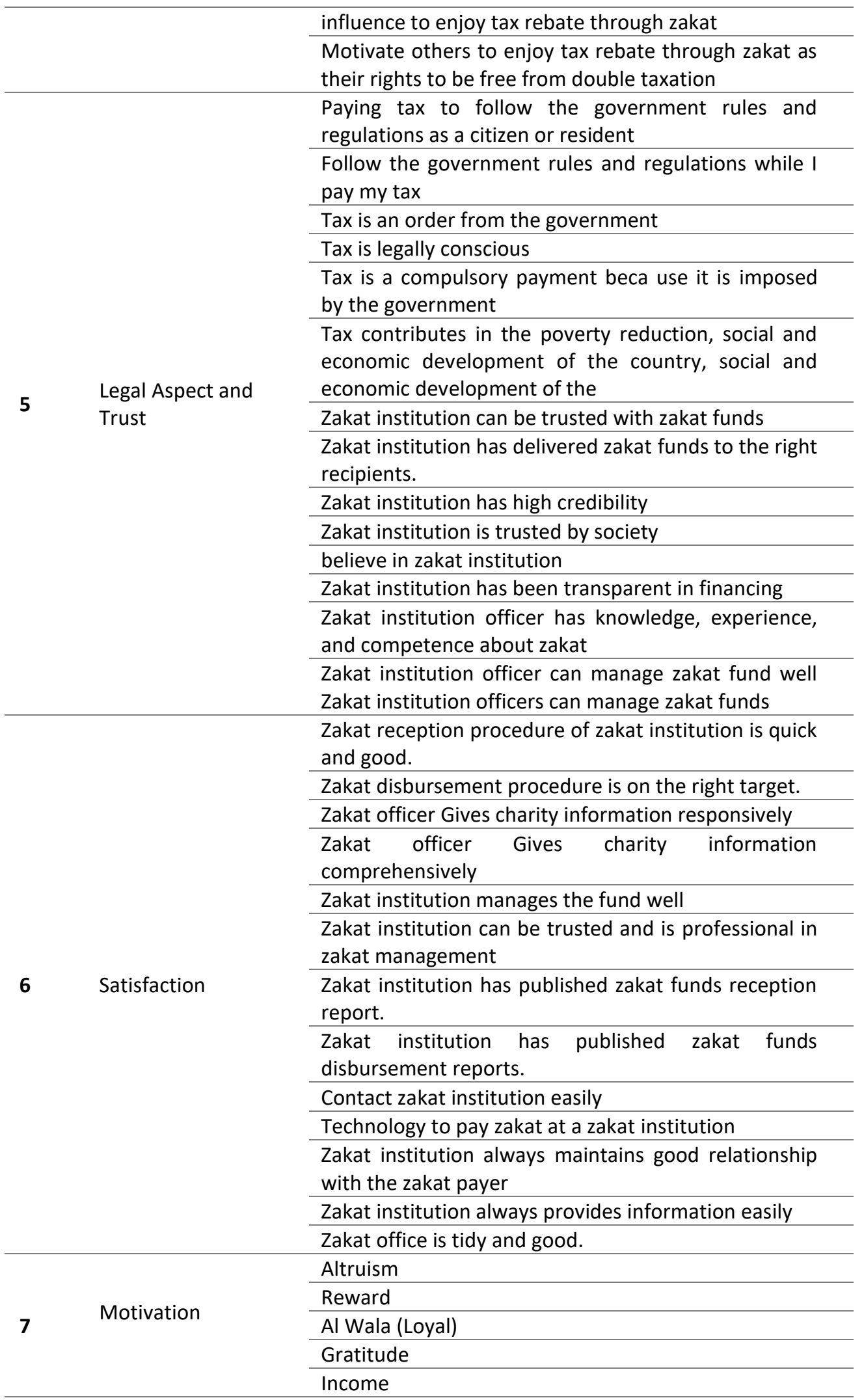

Published by University of Airlangga.

This is an open access article under the CC BY license (https://creativecommons.org/licenses/by-nc-sa/4.0/) 


\begin{tabular}{ll}
\hline & Procedure \\
\hline & $\begin{array}{l}\text { The way of paying zakat and getting tax rebate is } \\
\text { understandable and clear to me }\end{array}$ \\
\hline Acceptable to enjoy tax rebate through zakat \\
\hline Fairly treated by the government because I can avoid \\
double taxa tion of my earnings \\
\hline Tax rebate through zakat system will motivate \\
Merception \\
Toward Tax \\
Through Zakat
\end{tabular}$\quad \begin{aligned} & \text { Tax rebate through zakat system will increase the } \\
& \text { government's zakat fund }\end{aligned}$

\section{Data Analysis}

According to Noor (2013), data analysis techniques are a way of analyzing research data, including statistical tools that are relevant for use in research. The method used in data analysis and hypothesis testing in this study is by using the method Structural Equation Model - Partial Least Square (SEM-PLS). SEM is a statistical technique used to build and test statistical models which are usually in the form of causal models. SEM is able to explain the relationship of variables in a complex manner and as well as the direct or indirect effects of one or more variables on other variables. According to Abdillah and Hartono (2015), SEM prioritizes confirmatory modeling rather than exploratory modeling so it is more appropriate to use for theory testing (quantitative studies) than theory development (quantitative studies). Basically, PLS developed to test weak theories and weak data such as small sample sizes or data normality problems. Although PLS is used to explain whether there is a relationship between latent variables, it can also be used to confirm the theory (Chin, 1999).

Meanwhile, according to Abdillah and Hartono (2015), Partial Least Square (PLS) is a variant-based structural equation analysis (SEM) can simultaneously perform measurement model testing as well as structural model testing. The measurement model is used for the validity test and the reality test, while the structural model is used for the causality test (hypothesis testing with predictive models).

This study uses an undimensional construct with reflective indicators. The undimensional construct according to Ghozali and Latan (2015) is a construct that is formed directly from the manifest variable with the direction of the indicator being either reflexive or formative. Meanwhile, the construct with reflexive indicators assumes 
that the covariance between the model measurements is explained by the variant which is the manifestation of the construct domain. Based on this explanation, this research model can be described as follows:

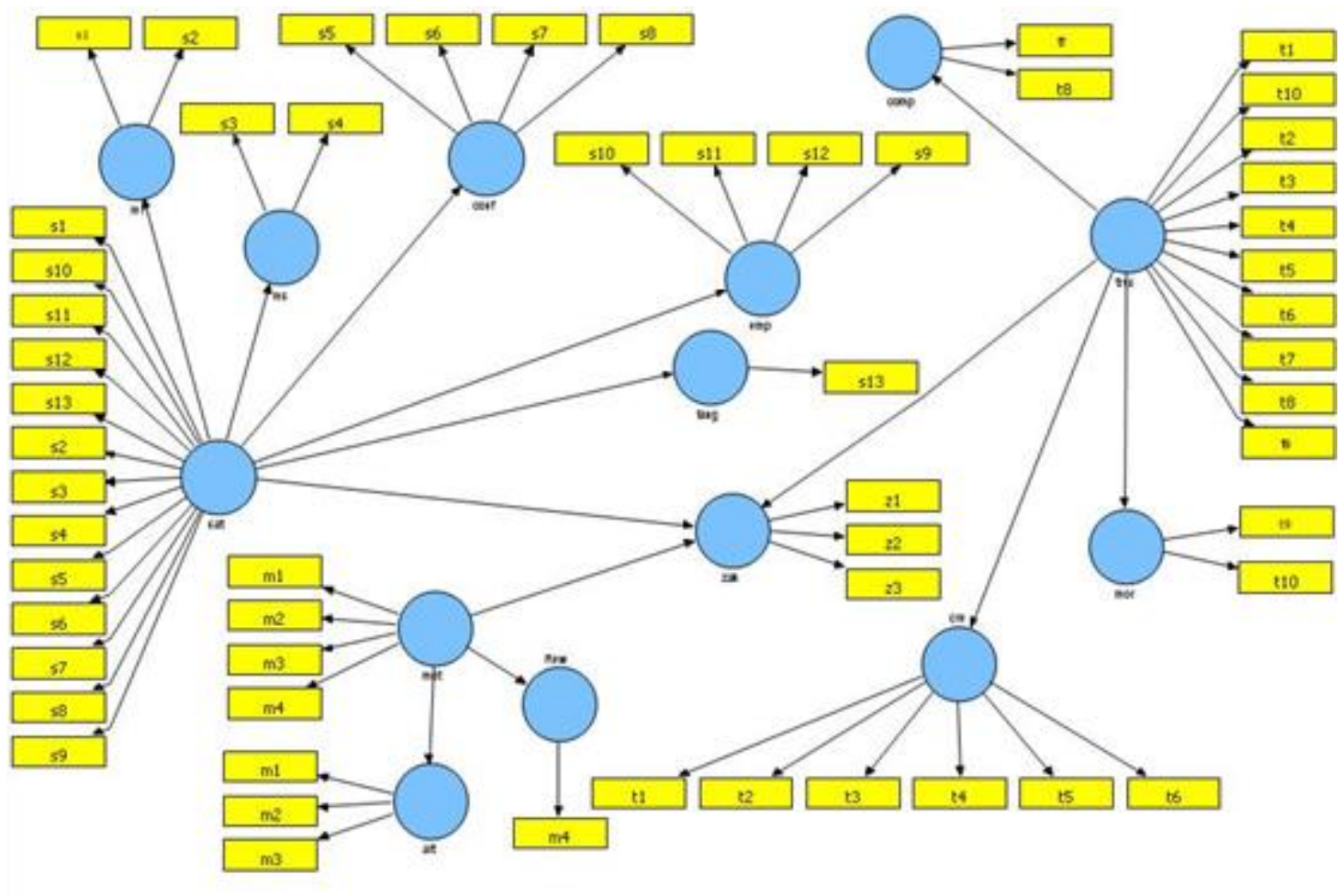

Figure 1. Research Model

\section{RESULT AND ANALYSIS}

\section{Distribution Frequency}

This research uses three technical stages of comprehensive analysis through demographic description of respondents based on Distributin Frequanty, then factor testing is carried out using Exploratory Factor Analysis (EFA) to select and determine the number of factors and related items, then in the final stage data analysis is carried out in the form ofmodeling technique. Structure equations model is used to test the quality of the models and hypotheses in this study. 
Table 2

Distribution Frequency

\begin{tabular}{|c|c|c|c|c|c|}
\hline \multicolumn{2}{|c|}{ Indicators } & \multirow{2}{*}{$\begin{array}{c}\text { Frequency } \\
60\end{array}$} & \multirow{2}{*}{$\begin{array}{c}\text { Percent } \\
39.5\end{array}$} & \multirow{2}{*}{$\begin{array}{c}\begin{array}{c}\text { Valid } \\
\text { Percent }\end{array} \\
39.5\end{array}$} & \multirow{2}{*}{$\begin{array}{c}\text { Cumulative } \\
\text { Percent }\end{array}$} \\
\hline Gender & Woman & & & & \\
\hline & Men & 92 & 60.5 & 60.5 & 100.0 \\
\hline & Total & 152 & 100.0 & 100.0 & \\
\hline \multirow[t]{3}{*}{ Citizens } & Malaysia & 77 & 50.7 & 50.7 & 50.7 \\
\hline & Indonesia & 75 & 49.3 & 49.3 & 100.0 \\
\hline & Total & 152 & 100.0 & 100.0 & \\
\hline \multirow[t]{5}{*}{ Ages } & 17 - 29 years & 51 & 33.6 & 33.6 & 33.6 \\
\hline & 30 - 39 years & 44 & 28.9 & 28.9 & 62.5 \\
\hline & 40 - 58 years & 54 & 35.5 & 35.5 & 98.0 \\
\hline & $>58$ years & 3 & 2.0 & 2.0 & 100.0 \\
\hline & Total & 152 & 100.0 & 100.0 & \\
\hline \multirow[t]{6}{*}{ Education } & High school & 11 & 7.2 & 7.2 & 7.2 \\
\hline & Diploma & 4 & 2.6 & 2.6 & 9.9 \\
\hline & Bachelor & 58 & 38.2 & 38.2 & 48.0 \\
\hline & Masters & 68 & 44.7 & 44.7 & 92.8 \\
\hline & Doctorate & 11 & 7.2 & 7.2 & 100.0 \\
\hline & Total & 152 & 100.0 & 100.0 & \\
\hline \multirow[t]{5}{*}{ Job } & Private & 62 & 40.8 & 40.8 & 40.8 \\
\hline & Civil & 69 & 45.4 & 45.4 & 86.2 \\
\hline & Entrepreneur & 20 & 13.2 & 13.2 & 99.3 \\
\hline & Apparatus & 1 & .7 & .7 & 100.0 \\
\hline & Total & 152 & 100.0 & 100.0 & \\
\hline \multirow[t]{5}{*}{ Income } & $<\$ 170$ & 31 & 20.4 & 20.4 & 20.4 \\
\hline & $\$ 170-\$ 230$ & 8 & 5.3 & 5.3 & 25.7 \\
\hline & $\$ 230-\$ 350$ & 24 & 15.8 & 15.8 & 41.4 \\
\hline & $>\$ 350$ & 89 & 58.6 & 58.6 & 100.0 \\
\hline & Total & 152 & 100.0 & 100.0 & \\
\hline
\end{tabular}

Source: SPSS Data Processed

In Table 2 known that of the 152 respondents who were sampled in this study, as many as 60 people (39.5\%) were female and 92 (60.5\%) were male. In addition, the majority of respondents are Malaysian citizens with 77 people $(50.7 \%)$ and the remaining 75 people (49.3\%) are Indonesian residents. Then there were 51 respondents (33.6\%) aged 17-29 years, and there were 44 respondents (28.9\%) aged 30-39 years, 55 respondents (35.5\%) aged $40-58$ years and there were 3 respondents (2\%) who were > 58 years.

Furthermore, based on Education respondent, it shows that there are eleven respondents (7.2\%) who have High school educational background, then Diploma as many as four respondents (2.6\%), Bachelor as many as 58 respondents (38.2\%), Masters as many as 68 respondents (44.7\%) and Doctorate as many as eleven respondents (7.2\%). Meanwhile, based on the job profile, the majority of respondents are private workers and civil servants with 62 people (40.8\%) and 69 people (45.4\%), besides that there are twenty respondents (13.2\%) whose jobs are entrepreneurs and only one 
respondent $(0.7 \%)$. who work as legal officers. Then it can be seen that the majority of respondents had an income of $<\$ 170$ for 31 people (20.4\%), \$170-\$230 for eight people (5.3\%), \$230 - \$ 350 with 24 people (15.8) and $>\$ 350$ for 89 people (58.6\%).

\section{Structural Equation Modelling (SEM) Test}

In the final stage, SEM testing is carried out on the factors that form Perception toward Tax through Zakat System produced by the method of Exploratory Factor Analysis with the aim of measuring the constructs of the relationship between manifest and latent variables and analyzing the relationship between variables based on the results of mathematical representation (Danks et al., 2020; Memon \& Rahman, 2014).

Table 3

Discriminant Validity of Outer Loading

\begin{tabular}{|c|c|c|c|c|c|c|c|c|}
\hline Indicator & KT & $\mathbf{K Z}$ & $\mathbf{M}$ & PTZS & $\mathbf{R}$ & $\mathbf{S}$ & $\mathbf{T}$ & A \\
\hline KT1 & 0.952 & & & & & & & \\
\hline KT2 & 0.820 & & & & & & & \\
\hline KZ1 & & 0.735 & & & & & & \\
\hline KZ2 & & 0.714 & & & & & & \\
\hline KZ3 & & 0.841 & & & & & & \\
\hline KZ4 & & 0.784 & & & & & & \\
\hline M1 & & & 0.854 & & & & & \\
\hline M2 & & & 0.882 & & & & & \\
\hline M3 & & & 0.897 & & & & & \\
\hline M4 & & & 0.819 & & & & & \\
\hline PTZS1 & & & & 0.746 & & & & \\
\hline PTZS10 & & & & 0.860 & & & & \\
\hline PTZS2 & & & & 0.783 & & & & \\
\hline PTZS3 & & & & 0.882 & & & & \\
\hline PTZS4 & & & & 0.863 & & & & \\
\hline PTZS5 & & & & 0.857 & & & & \\
\hline PTZS6 & & & & 0.791 & & & & \\
\hline PTZS7 & & & & 0.841 & & & & \\
\hline PTZS8 & & & & 0.848 & & & & \\
\hline PTZS9 & & & & 0.890 & & & & \\
\hline R1 & & & & & 0.719 & & & \\
\hline $\mathbf{R 2}$ & & & & & 0.753 & & & \\
\hline R3 & & & & & 0.885 & & & \\
\hline R4 & & & & & 0.888 & & & \\
\hline R5 & & & & & 0.832 & & & \\
\hline R6 & & & & & 0.841 & & & \\
\hline
\end{tabular}




\begin{tabular}{ll}
\hline S1 & 0.924 \\
\hline S2 & 0.962 \\
\hline T1 & 0.824 \\
\hline T10 & 0.897 \\
\hline T11 & 0.792 \\
\hline T12 & 0.774 \\
\hline T13 & 0.902 \\
\hline T14 & 0.903 \\
\hline T15 & 0.853 \\
\hline T16 & 0.858 \\
\hline T17 & 0.701 \\
\hline T2 & 0.843 \\
\hline T3 & 0.874 \\
\hline T4 & 0.888 \\
\hline T5 & 0.843 \\
\hline T6 & 0.884 \\
\hline T7 & 0.821 \\
\hline T8 & 0.867 \\
\hline T9 & 0.846 \\
\hline A1 & \\
\hline
\end{tabular}

Souce: Data Processed

Note: $\mathrm{KT}=$ Knowledge of Tax; $\mathrm{KZ}=$ Knowledge of Zakat; $\mathrm{M}=$ Motivation; PTZS = Perception about Tax and Zakat System; R = Religiosity; $\mathrm{S}=$ Satisfaction; $\mathrm{T}=$ Trust; $\mathrm{A}=$ Halal Haram Aspect

Table 3 shows that the results of outer loading on the form explonatory factor analysis factor can be seen that all indicators used in this test are above the threshold value of 0.7 (Farrell \& Rudd, 2009; Hair et al., 2018), meaning that all items on the indicator are valid. and can be used for testing the next stage. Then to ensure the quality of the data in this study, a discriminant validity test was carried out through the FornellLarcker Criterion with a threshold of 0.7 on variable correlation (Hamid et al., 2017; Henseler et al., 2015), as follows:

Table 4

Discriminant Test

\begin{tabular}{ccccccccc}
\hline Indicator & KT & KZ & M & PTZS & $\mathbf{R}$ & $\mathbf{S}$ & $\mathbf{T}$ & $\mathbf{A}$ \\
\hline KT & 0.889 & & & & & & & \\
\hline KZ & 0.140 & 0.770 & & & & & & \\
\hline M & 0.201 & 0.593 & 0.863 & & & & & \\
\hline PTZS & 0.403 & 0.417 & 0.471 & 0.837 & & & & \\
\hline R & 0.295 & 0.456 & 0.397 & 0.741 & 0.822 & & & \\
\hline S & 0.316 & 0.356 & 0.468 & 0.551 & 0.359 & 0.943 & & \\
\hline T & 0.411 & 0.248 & 0.458 & 0.534 & 0.450 & 0.759 & 0.847 & \\
\hline A & 0.262 & 0.251 & 0.254 & 0.469 & 0.532 & 0.267 & 0.308 & 1.000 \\
\hline
\end{tabular}

Source: Data Processed 
Table 4 shows that all indicators in this test have a Fornell-Larcker Criterion value above the threshold value of 0.7 with Knowledge about Tax (0.889), Knowledge about Zakat (0.770), Motivation (0.863), Perceptions about Tax and Zakat System (0.837), Religiosity (0.822), Halam Halam Aspect (0.883), Satisfaction values (0.943), Trust (0.847) and Legal Aspect $(1,000)$, so that it can be continued in reliability testing through the Cronbach's Alpha value of 0.7 , Composite Reliability of 0.7 and Average Variance Extracted (AVE) of 0.5 (Ab Hamid et al., 2017; Chan \& Lay, 2018; Cheah et al., 2018), as follows:

Table 5

Reliability Test

\begin{tabular}{cccc}
\hline Indicators & Cronbach's Alpha & Composite Reliability & Average Variance Extracted (AVE) \\
\hline KT & 0.755 & 0.882 & 0.790 \\
\hline KZ & 0.776 & 0.853 & 0.593 \\
\hline M & 0.892 & 0.921 & 0.746 \\
\hline PTZS & 0.952 & 0.959 & 0.701 \\
\hline R & 0.903 & 0.926 & 0.676 \\
\hline S & 0.879 & 0.941 & 0.889 \\
\hline T & 0.975 & 0.977 & 0.717 \\
\hline A & 1.000 & 1.000 & 1.000 \\
\hline
\end{tabular}

Source: Data Processed

Table 5 shows that all indicators used in this study have a value that is higher than the threshold for reliability testing based on Cronbach's Alpha, Composite Reliability and Average Variance Extracted (AVE), meaning that each indicator is considered to have met the validity of measuring items in forming latent variables (Roni et al., 2015). Then, in the final stage, testing is carried out between the variables of the exploratory factor analysis formation against the perception toward tax through zakat system variable, through the path coefficient as follows. 


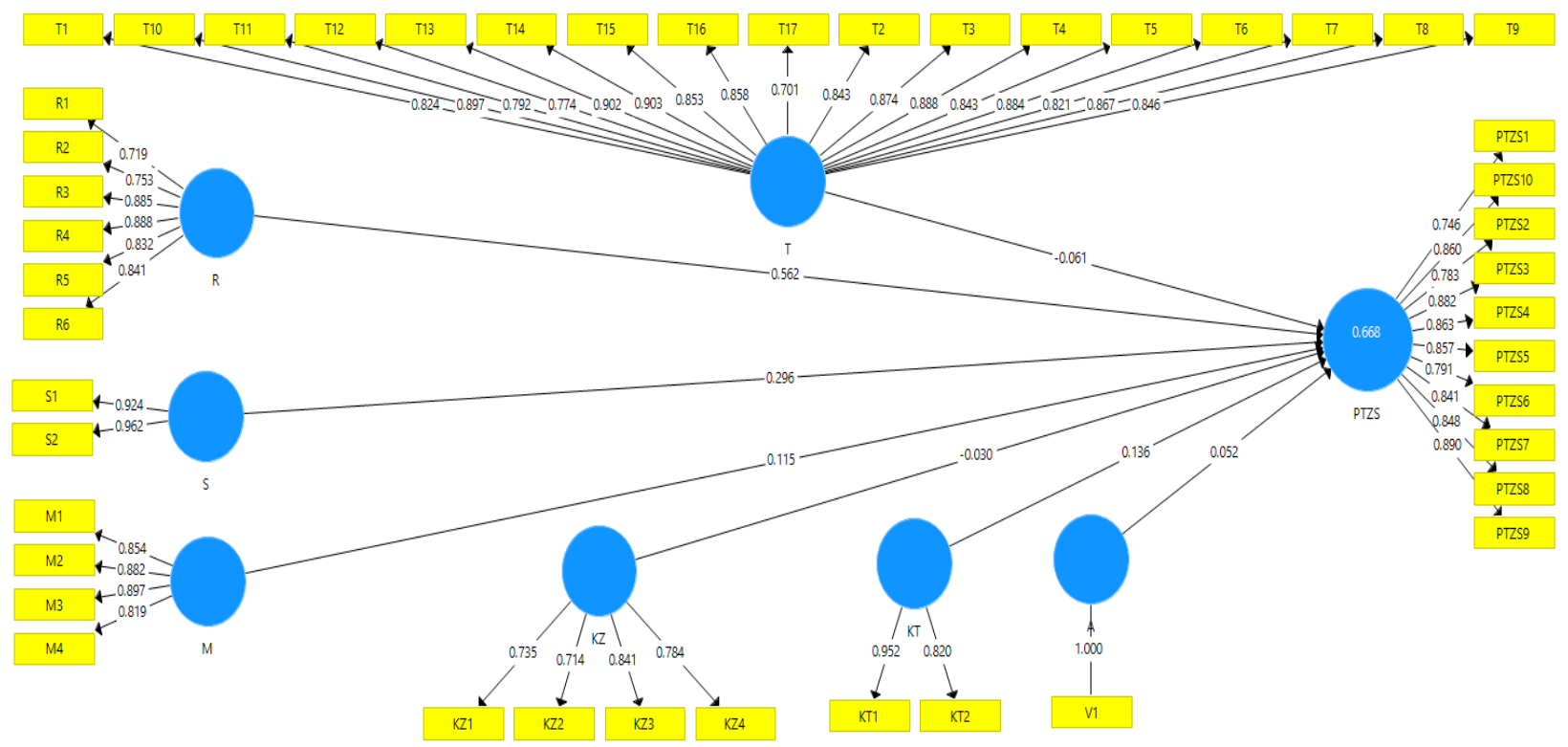

Figure 2. Result of Structure Equations Model (SEM)

Table 6

Path Coefficient and R Square

\begin{tabular}{|c|c|c|c|c|c|c|}
\hline & $\begin{array}{c}\text { Original } \\
\text { Sample (0) }\end{array}$ & $\begin{array}{c}\text { Sample } \\
\text { Mean (M) }\end{array}$ & $\begin{array}{c}\text { Standard Deviation } \\
\text { (STDEV) }\end{array}$ & $\begin{array}{l}\text { T Statistics } \\
\text { (|O/STDEV|) }\end{array}$ & P Values & Note \\
\hline KT -> PTZS & 0.136 & 0.147 & 0.065 & 2.103 & $0.036 *$ & Support \\
\hline KZ -> PTZS & -0.030 & -0.004 & 0.077 & 0.394 & 0.694 & $\begin{array}{c}\text { Not } \\
\text { Support }\end{array}$ \\
\hline M -> PTZS & 0.115 & 0.121 & 0.060 & 1.905 & 0.057 & $\begin{array}{c}\text { Not } \\
\text { Support }\end{array}$ \\
\hline R -> PTZS & 0.562 & 0.552 & 0.072 & 7.789 & $0.000 *$ & Support \\
\hline S -> PTZS & 0.296 & 0.281 & 0.084 & 3.517 & $0.000^{*}$ & Support \\
\hline T -> PTZS & -0.061 & -0.055 & 0.095 & 0.649 & 0.517 & $\begin{array}{c}\text { Not } \\
\text { Support }\end{array}$ \\
\hline A $->$ PTZS & 0.052 & 0.050 & 0.066 & 0.796 & 0.426 & $\begin{array}{c}\text { Not } \\
\text { Support }\end{array}$ \\
\hline $\begin{array}{l}\text { R Square } \\
\text { of PTZS }\end{array}$ & & & 0.668 & & & \\
\hline $\begin{array}{l}\text { R Square } \\
\text { Adjusted } \\
\text { of PTZS }\end{array}$ & & & 0.652 & & & \\
\hline
\end{tabular}

Source: Data Processed

The test results in table 6 shows that the relationship between knowledge about tax and perceptions about tax and zakat system has a path coefficient level of 0.136 with a significance of 0.036 , meaning that knowledge about tax has a positive influence on perceptions about tax and zakat system. Palil (2005) stated that knowledge of taxes is the most important part of achieving tax optimization, besides that a good understanding of the rules and functions of tax is predicted to be able to encourage an 
increase in income in the tax sector, so as to create better welfare for the community (Al-Mamun et al., 2020; Al-Mamun \& Haque, 2015; Djatmiko, 2019).

Then, based on the test results it shows that knowledge about zakat has an efficiency value of -0.030 with a significance level of 0.694 , meaning that there is no significant relationship between knowledge about zakat and perceptions about tax and zakat system. This is because there are still deficiencies in zakat regulation that limit the optimization of zakat, because a good understanding without the support of clear regulations can affect perception toward the tax through zakat system (Saad \& Al-Foori, 2020).

Testing on the relationship between motivation and perceptions about tax and zakat system, the level of motivation's coefficient of 0.115 with a significance of 0.057 , meaning that there is no significant relationship and influence each other between the two variables. Nurhayati and Siswantoro (2015) stated that basically motivation does not have a significant effect on the perception toward tax through zakat system. This is because zakat is positioned as a tax cutter which has an impact on reducing government revenue. In addition, people kicking taxes is something that must be done even if there is no reduction in taxes (Bakar \& Rashid, 2010).

The analysis of the influence of religiosity on perceptions about tax and zakat system show that there is a coefficient value of 0.562 with a significance of 0.000 in the variable religiosity. It means that there is a positive relationship and significant between religiosity and perceptions about tax and zakat system. Djatmiko (2019) stated that zakat is a religious obligation for Muslims, so that it becomes binding. because Religiosity plays a role in influencing individual moral decisions through its commitment to carrying out religious orders (Adachi, 2018; Wiliasih et al., 2011). Table 6 shows that the results of the analysis on the satisfaction relationship to PTZS show a coefficient value of 0.296 with a significance level of 0.000 , meaning the variable satisfaction able to provide a positive and significant influence on perceptions about tax and zakat system. Al-Mamun et al. (2020) explained that the zakat performance of an institution is highly dependent on the quality of services provided, so it is important for the institution to provide the best service in order to increase optimization in the zakat and tax sector (Zainal et al., 2016).

The test results show that the trust variable has a coefficient value of -0.061 with a significance value of 0.517 , meaning that there is no significant relationship between the trust variable and perceptions about tax and zakat system. Fauziati et al. (2020) stated that trust does not provide a significant effect as a reinforcement in the relationship of knowledge about taxes on tax payments, but it takes a good reputation in tax management so that it can influence perception toward tax through zakat system (Muhammad \& Saad, 2016). Testing on variable halal and haram aspect on perceptions 
about tax and zakat system shows a coefficient value of 0.052 with a significance of 0.426 , meaning that there is no significant influence between the two variables so that halal and haram aspect cannot affect perceptions about tax and zakat system. This is because the obligation to give zakat is seen as not an essential thing of religious compliance, so that Individuals often think that the wealth they get is the result of their hard work, especially private sector workers (Anwar \& Arifin, 2018).

In the results of the feasibility test of the model, the determinant coefficient value ( $R$ Square) was 0.668 , meaning that the model used in the perceptions about tax and zakat system measurement was categorized as good. In addition, through the value of R Square, it can be said that the model used in this study can explain the construct for the perceptions about tax and zakat system variable by $66.8 \%$ and the rest is explained by other variables not included in this research model.

\section{CONCLUSION}

This study aims to examine the model adopted based on Muslim consumer perceptions of taxes through the zakat system. At the testing stage of the model through the Structural Equation Model (SEM) based on the results of the formation factors in the test, it EFA can be said that only the Knowledge about Tax, Religious and Service variables have an impact on Perception toward Tax through Zakat System positively and significantly, but through Testing the serviceability of a model results in a determinant coefficient ( $R$ Square) of 0.668 , meaning that the model used in the PTZS measurement is in a good category.

The recommendation of this research is to encourage the government to suppress the increase in making taxpayer numbers, because without a taxpayer number, the government will find it difficult to optimize the tax deduction program through zakat. In addition, the government must guarantee legal certainty in determining zakat as a tax cut. Furthermore, the government can collaborate with religious leaders in socializing the program, so that literacy in tax reduction programs through zakat can be known to the whole community. Then in order to optimize the program, this program should be carried out under the supervision and coordination of the Ministry of Finance and the Ministry of Religion, so that the performance of the institution can run optimally.

This study needs to improve with another variable which is still exist outside this paper. This analysis has limitation because we do not compare about perception about zakat system of Indonesian and Malaysian Moslem.

\section{ACKNOWLEDGMENT}

We thank the guest editors for valuable comments which have improved the exposition of our paper and we are also thankful to Yogyakarta State University for the funding of this research. 


\section{REFERENCES}

Abdillah, W., \& Hartono, J. (2015). Partial Least Square: Alternative Structural Equation Model (SEM) dalam Penelitian Bisnis. Andi.

Adachi, M. (2018). Discourses of Institutionalization of Zakat Management System in Contemporary Indonesia: Effect of the Revitalization of Islamic Economics. International Journal of Zakat, 3(1), 25-35. https://doi.org/10.37706/ijaz.v3i1.71

Al-Mamun, A., \& Haque, A. (2015). TAX DEDUCTION THROUGH ZAKAT: AN EMPIRICAL INVESTIGATION ON MUSLIM IN MALAYSIA. Jurnal Ekonomi Dan Keuangan Islam, 4(2). https://doi.org/10.22373/share.v4i2.1027

Al-Mamun, A., Haque, A., \& Jan, M. T. (2020). Measuring perceptions of Muslim consumers toward income tax rebate over zakat on income in Malaysia. Journal of Islamic Marketing, 11(2), 368-383. https://doi.org/10.1108/JIMA-12-20160104

Al-Mawardi, I. (2006). Al-Hakam As-Sulthaniyyah: Hukum-Hukum Penyelenggaraan Negara dalam Syariat Islam. Darul Falah.

Al Jaffri Saad, R., \& Haniffa, R. (2014). Determinants of zakah (Islamic tax) compliance behavior. Journal of Islamic Accounting and Business Research, 5(2), 182-193. https://doi.org/10.1108/JIABR-10-2012-0068

An-Nabahan, M. F. (2000). Sistem Ekonomi Islam (Pilihan Setelah Kegagalan Sistem Kapitalis dan Sosialis). UII Press.

Anwar, A. Z., \& Arifin, M. (2018). The Degree Of Understanding Of Zakat On Profession/Income In Jepara Regency. Jurnal IImiah Al-Syari'ah, 16(2). https://doi.org/10.30984/jis.v16i2.665

Arif, H. M., Alwi, K., \& Tahir, A. M. (2011). Factors Influence Company towards Zakat Payment: An Ex[lanatory Studies. 2nd ICBER 2011 PROCEEDING.

At-Tuwaijiri, A.-T. (2012). Ringkasan Fiqh Islam. Islamhouse.

Azman, F. M. N., \& Bidin, Z. (2015). Factors influencing zakat compliance behavior on saving. International Journal of Business and Social Research, 05(01), 118-128.

Bakar, N. B. A., \& Rashid, H. M. A. (2010). Motivations of Paying Zakat on Income: Evidence from Malaysia. International Journal of Economics and Finance, 2(3). https://doi.org/10.5539/ijef.v2n3p76

Bakar, N. B. A., Saleh, Z., \& Mohamad, M. H. S. (2011). Enhancing Malaysian Public Sector Transparency and Accountability: Lessons and Issues. European Journal of Economics, Finance, and Administrative Sciences, 31.

Chin, W. W. (1999). The Partial Least Square Approach to Structural Equation Modeling. In Modern Methods for Business Research. Lawrence Erlbaum Associates.

Dahlan, T. (2008). "Faktor faktor yang mempengaruhi intensitas muzakki menunaikan zakat pada baitul mal masjid jami an-nur. Jurnal Ekonomi Keuangan Dan Bisnis, 1(4), 72.

Danks, N. P., Sharma, P. N., \& Sarstedt, M. (2020). Model selection uncertainty and multimodel inference in partial least squares structural equation modeling (PLS- 
Jurnal Ekonomi dan Bisnis Islam, Vol. 7, No. 2, July - December 2021

SEM). Journal of Business Research, 113, 13-24.

https://doi.org/10.1016/j.jbusres.2020.03.019

Djatmiko, H. (2019). Re-formulation zakat system as tax reduction in Indonesia.

Indonesian Journal of Islam and Muslim Societies, 9(1).

https://doi.org/10.18326/ijims.v9i1.135-162

Farrell, A. M., \& Rudd, J. M. (2009). Factor analysis and discriminant validity:a brief review of some practical issues. In D. Tojib (Ed.), ANZMAC 2009.

http://publications.aston.ac.uk/id/eprint/7644/

Fatah, D. A. (2008). Faktor-Faktor yang Mempengaruhi Preferensi Karyawan Pertamina dalam Membayar Zakat Pofesi Melalui Baituzzakah Pertamina. Jurnal Ekonomi Keuangan Dan Bisnis.

Fauziati, P., Minovia, A. F., Muslim, R. Y., \& Nasrah, R. (2020). The Impact of Tax Knowledge on Tax Compliance Case Study in Kota Padang, Indonesia. Journal of Advanced Research in Business and Management Studies, 2(1), 22-30. https://www.akademiabaru.com/submit/index.php/arbms/article/view/1183

Firdaus, M., Beik, I. S., Irawan, T., \& Juanda, B. (2012). Economic Estimation and Determinations of Zakat Potential in Indonesia (No. 1433-07).

Gilligan, G., \& Richardson, G. (2005). Perceptions of tax fairness and tax compliance in Australia and Hong Kong - a preliminary study. Journal of Financial Crime, 12(4), 331-343. https://doi.org/10.1108/13590790510624783

Hair, J. F., Sarstedt, M., Ringle, C. M., \& Gudergan, S. P. (2018). Advanced Issues in Partial Least Squares Structural Equation Modeling. Sage Publications.

Hamid, M. R. A., Sami, W., \& Sidek, M. H. M. (2017). Discriminant Validity Assessment: Use of Fornell \& Larcker criterion versus HTMT Criterion. Journal of Physics: Conference Series, 890. https://iopscience.iop.org/article/10.1088/1742$6596 / 890 / 1 / 012163$

Hamidiyah, E. (2008). Analisis Faktor-Faktor Yang Mempengaruhi Pengumpulan Zakat, Infak, Shadaqah, Wakaf Dan Kurban Pada Lembaga Pengelola Zakat (Studi Kasus: Dompet Dhuafa'Republika). Jurnal EKonomi Islam Dan Bisnis Islam (EKSIS), 4.

Hanno, D. M., \& Violette, G. R. (1996). An analysis of moral and social influences on taxpayer behavior. Behavioral Research in Accounting, 8, 57-75.

Hanson, A. (2021). Taxes and Economic Development: An Update on the State of the Economics Literature. Economic Development Quarterly, 35(3), 232-253. https://doi.org/10.1177/08912424211022832

Henseler, J., Ringle, C. M., \& Sarstedt, M. (2015). A new criterion for assessing discriminant validity in variance-based structural equation modeling. Journal of the Academy of Marketing Science, 43(1), 115-135. https://doi.org/10.1007/s11747-014-0403-8

Huda, N., Anggraini, D., Ali, K. M., Mardoni, Y., \& Rini, N. (2014). Prioritas Solusi Permasalahan Pengelolaan Zakat di Propinsi Banten dan Kalimantan Selatan dengan Metode AHP. Al-lqtishad: Jurnal Ilmu Ekonomi Syariah, 6(2), 223-238. https://doi.org/10.15408/aiq.v6i2.1232

Idris, K. M., Bidin, Z., \& Saad, R. A. J. (2012). Islamic religiosity measurement and its relationship with business income zakat compliance behavior. Jurnal Pengurusan, 
34.

Indahsari, K. (2013). Preferensi Individu Muslim Dalam Penyaluran Zakat, Infak, Shadaqah dan Waqaf (ZISWA): Kendala Pembangunan Sektor Ketiga. Media Trend, 8(2), 101-117.

Irhamsyah, A. (2019). Analisis Faktor-Faktor Preferensi yang Mempengaruhi Keputusan Metode Pembayaran Zakat Bagi Muzakki di Era Digital (Studi pada Dosen dan Tenaga Kependidikan Fakultas Ekonomi dan Bisnis Universitas Brawijaya). Jurnal IImiah Mahasiswa FEB Universitas Brawijaya, 8(1). https://jimfeb.ub.ac.id/index.php/jimfeb/article/view/6157

Jackson, B. R., \& Milliron, V. C. (1986). Tax compliance research, findings and problems and prospects. Journal of Accounting Literature, 5(1), 125-165.

Jaelani, A. (2008). Pengelolaan Zakat untuk Pengentasan Kemiskinan di Indonesia dan Brunei Darussalam. TInjauan Ekonomi Turki, 3(3).

Khamis, M. R. bin, Salleh, A. M., \& Nawi, A. S. (2011). Compliance Behavior of Business Zakat Payment in Malaysia: A Theoretical Economic Exposition. 8th International Conference on Islamic Economics and Finance.

Khraim, H. (2010). Measuring Religiosity in Consumer Research From an Islamic Perspective. Journal of Economic and Administrative Sciences, 26(1), 52-78. https://doi.org/10.1108/10264116201000003

Kotler, P., \& Armstrong, G. (1997). Dasar-Dasar Pemasaran (1st ed.). Prenhallindo. Ma'fiyah, M., Yughi, S. A., \& Awaludin, T. (2018). Preferensi Muzakki Dalam Memilih Membayar Zakat di Lembaga Zakat Formal. AL-FALAH : Journal of Islamic Economics, 3(2). https://doi.org/10.29240/alfalah.v3i2.535

Memon, A. H., \& Rahman, I. A. (2014). SEM-PLS Analysis of Inhibiting Factors of Cost Performance for Large Construction Projects in Malaysia: Perspective of Clients and Consultants. The Scientific World Journal, 2014, 1-9. https://doi.org/10.1155/2014/165158

Merlinda, S., Burhan, U., \& Ekawaty, M. (2016). The Determinant of Moslem's Decision in Performing Commerce Zakat Payment: Case Study in Malang City, East Java Province. Social and Local Economy Governance, 2(1). https://doi.org/10.21776/ub.ijleg.2016.002.01.7

Mohammed, M. O., Razak, D. A., \& Taib, F. M. (2008). The Performance Measures of Islamic Banking Based on The Maqashid syariah. Proceeding INTAC IV.

Muda, M., Marzuki, A., \& Shaharuddin, A. (2009). Factors influencing individual participation in zakat contribution: Exploratory investigation.

Muhammad, S. A., \& Saad, R. A. J. (2016). Determinants of trust on zakat institutions and its dimensions on intention to pay zakat: A pilot study. Journal of Advanced Research in Business and Management Studies, 3(1), 40-46. http://repo.uum.edu.my/19496/

Mukhlis, A., \& Beik, I. S. (2013). Analisis Faktor-faktor yang Memengaruhi Tingkat Kepatuhan Membayar Zakat: Studi Kasus Kabupaten Bogor. Al-Muzara'ah, 1(1). https://doi.org/10.29244/jam.1.1.83-106 
Mustafa, M. O. A., Mohamad, M. H. S., \& Adnan, M. A. (2013). Antecedents of zakat payers' trust in an emerging zakat sector: an exploratory study. Journal of Islamic Accounting and Business Research, 4(1), 4-25. https://doi.org/10.1108/17590811311314267

Nasution, M. E. (2009). Indonesia Zakat \& Development Report 2009. PEBS.

Noor, J. (2013). Penelitian IImu Manajemen, Tinjauan Filosofis, dan Praktis (1st ed.). Kencana.

Nurhayati, S., \& Siswantoro, D. (2015). Factors on Zakat (Tithe) Preference as a Tax Deduction in Aceh, Indonesia. International Journal of Nusantara Islam, 3(1). https://doi.org/10.15575/ijni.v3i1.133

Palil, M. R. (2005). Taxpayers Knowledge: a Descriptive Evidence on Demographic Factors in Malaysia. Jurnal Akuntansi Dan Keuangan, $7(1)$. https://ojs.petra.ac.id/ojsnew/index.php/aku/article/view/16322

PIRAC. (2002). Pola dan Kecenderungan Masyarakat Berzakat: Hasil Survey Sebelas Kota di Indonesia. PIRAC.

Richardson, M., \& Sawyer, A. J. (2001). A Taxonomy of the Tax Compliance Literature: Further Findings, Problems and Prospects. Australian Tax Forum, 16.

Roni, S. M., Djajadikerta, H., \& Ahmad, M. A. N. (2015). PLS-SEM Approach to Secondorder Factor of Deviant Behaviour: Constructing Perceived Behavioural Control. Procedia Economics and Finance, 28, 249-253. https://doi.org/https://doi.org/10.1016/S2212-5671(15)01107-7

Saad, A. Y. Q., \& Al-Foori, A. M. (2020). Zakat and Tax: A Comparative Study in Malaysia. International Journal of Innovation, Creativity and Change, 10(12), 140-151.

Sabiq, S. (2019). Fiqih Sunnah. Pustaka Percetakan Offset.

Sugiyono, S. (2011). Metode Penelitian Kualitatif, Kuantitatif, dan kombinasi. Alfabeta.

Wahid, H., Noor, M. A. M., \& Ahmad, S. (2005). Kesedaran Membayar Zakat: Apakah Faktor Penentunya? International Journal of Management Studies, 12(2). http://www.e-journal.uum.edu.my/index.php/ijms/article/view/9219

Wiliasih, R., Usman, H., Marzuki, K., Mardoni, Y., \& Marcelo, M. (2011). Relationship between Quality of Life and Regular Zakah Exercise. International Journal of Business and Social Science, 2(16), 173-180.

Zaim, S. (1989). Recent Interpretations of The Economic Aspects of Zakah. In I. A. Imtiazi, M. A. Mannan, M. A. Niaz, \& A. H. Deria (Eds.), Management of Zakah in Modern Muslim Society (1st ed.). Islamic Development Bank.

Zainal, H., Bakar, A. A., \& Saad, R. A. J. (2016). The Role of Reputation, Satisfactions of Zakat Distribution, And Service Quality in Developing Stakeholder Trust In Zakat Institutions. The European Proceedings of Social \& Behavioural Sciences. 